Техніка і технології тваринництва Engineering and technology livestock

УДК 621.9.048.4

https://doi.org/10.37700/enm.2020.2(16).38 - 44

\title{
Удосконалення способу подрібнення кормів молотковими дробарками
}

\author{
В.Б. Тарельник ${ }^{1}$, Є.В. Коноплянченко ${ }^{2}$, Є.М. Гецович ${ }^{3}$, М.Я. Довжик ${ }^{4}$ \\ Сумський національний аграрний університет, (м. Суми, Україна) \\ email: ${ }^{1}$ tarelnyk@ukr.net, ${ }^{2}$ konoplyanchenko@ukr.net, ${ }^{3}$ e.getsovich@i.ua, \\ 4 dovgukm@ukr.net, ORCID: ${ }^{1}$ 0000-0003-2005-5861, ${ }^{2}$ 0000-0003-4814-1796, \\ ${ }^{3}$ 0000-0003-4868-1573, ${ }^{4}$ 0000-0002-1627-4888
}

\begin{abstract}
Приведені переваги та недоліки способу подрібнення зерна молотковими дробарками. При цьому до загальних недоліків різних типів подрібнювачів віднесені: висока енергоємність, необхідність додаткового подрібнення часток, інтенсивне спрацювання робочих органів і зв'язку з цим невеликий експлуатаційний період молоткової дробарки, низька якість та рівномірність подрібнення. В якості основного недоліку багатоступінчастих способів подрібнювання кормів вказано те, що матеріал корму проходить обробку через декілька подрібнювачів і кінцевий ступінь подрібнення досягається поступово, при цьому застосовується більш складне, а значить і менш надійне встаткування. Обґрунтовано застосування одноступінчастого способу подрібнення. В роботі описана технологія збільшення експлуатаційного періоду молоткової дробарки та поліпшення якості і рівномірності подрібнення кормів, шляхом вдосконалення процесу одноступінчастого способу подрібнення, за рахунок формування методом електроіскрового легування (ЕІЛ) на робочих поверхнях молотка та гребінки покриттів з зносостійких матеріалів. Наведено результати легування зразків сталі 65Г, з використанням різних режимів на установці моделі «Елітрон 52А», з метою визначення впливу енергетичних параметрів ЕІЛ на параметри якості покриттів, нанесених електродами складу 10\% $1 \mathrm{M}+90 \%$ ВК6. Запропонований новий спосіб подрібнення кормів молотковими дробарками. Спосіб відрізняється тим, що на більш наближених поверхнях молотка та гребінки (деки) методом ЕІЛ наносять покриття з зносостійких матеріалів, причому наносять таким чином, що їх товщина та шорсткість, по мірі просування молотка вздовж поверхонь гребінки (деки) поступово збільшуються, а величина зазору між ними, відповідно, зменшується. Покриття наносять на повітрі окремими ділянками шириною 5-7 мм, при енергіях розряду - 0,2; 0,52; 2,6 і 4,6 Дж; продуктивністю - 0,5 - 0,8; 1,0 - 1,3; 1,5 - 2,0 і 2,0 - 2,5 cм²/хв; товщиною - 0,02; 0,12; 0,19 і 0,23 мм і шорсткістю, (Rz) -7; 21; 65 і 117 мкм, відповідно. В якості матеріалу електроду використовують електрод-інструмент складу 10\% 1M + 90\% ВК6. В результаті збільшується експлуатаційний період молоткової дробарки, знижуються енерговитрати, поліпшується якість та рівномірності подрібнення.
\end{abstract}

Ключові слова: молоткова дробарка, молоток, дека, знос, шорсткість, мікротвердість, електроіскрове легування.

Вступ. В усьому світі корми для тварин прийнято подрібнювати. При розмелі зовнішня поверхня частинок корму багатократно збільшується в порівнянні із не подрібненим кормом, а їх товщина зменшується. Відповідно, поліпшуються умови перетравлювання корму та його всмоктування у кишково- шлунковому тракті. Для досягнення кращої однорідності, при перемішуванні сухих речовин, важливо, щоб частинки були співрозмірної величини.

В агропромисловому комплексі нашої країни останнім часом намітилася стійка тенденція на наближення виробництва комбікормів безпосередньо до споживачів комбікормової продукції і місцевих сировинних ресурсів. Це обумовлено в першу чергу значними темпами росту вартості комбікормової продукції.

Приготування корму безпосередньо в господарствах дозволяє значно знизити витрати на транспортні операції, ширше використовувати дешеві місцеві сировинні ресурси й надійно забезпечувати господарство комбікормами. Все це дозволяє істотно скоротити собівартість вироблених кормів [1].

Однією з важливих і самих енергоємних операцій у технології кормоприготування $€$ подрібнення. Для подрібнення зерна застосовують різни типи подрібнювачів. 
Молоткові кормодробарки застосовують на борошномельних і круп'яних заводах, на комбікормових заводах, середніх та малих тваринницьких комплексах (фермерських сільськогосподарських підприємствах) та індивідуальному використанні у господарстві для подрібнення зерна та продуктів його переробки. На сьогодні існує велика кількість молоткових кормодробарок різних як за своїм призначенням, так і за принципом дії робочих органів на зерно (стисненням, стиранням, зрушенням, ударом, сколюванням) [2].

Аналіз основних досягнень і публікацій

Відомий спосіб подрібнення зерна молотковими дробарками, які отримали найбільше розповсюдження, та найбільш повно задовольняють вимогам, пропонованим до машин, що подрібнюють і мають цілий ряд переваг у порівнянні з іншими машинами того ж призначення. Але молоткові дробарки мають суттєвий недолік. В конструкції молоткових дробарок закладені принципи подрібнення зерна, що обумовлюють переподрібнення значної частини маси. Потрапляючи в зону молотків, великі частки, маючи більшу інерційність, розміщаються на периферії шару на поверхні решета. Вони закривають вихід більш дрібним часткам, які відтискуються до центра обертання ротора й додатково подрібнюються, що веде до зниження якості одержуваного продукту та підвищенню енерговитрат [3].

Технологічні схеми подрібнення зерна сьогодні розвиваються в напрямку зниження енерговитрат, поліпшення якості, рівномірності подрібнення, розширення технологічних можливостей, повної механізації завантаження й вивантаження, а також раціональної організації робочого процесу подрібнення.

Також відомі багатоступеневі способи подрібнення кормів, які одержали розвиток завдяки зниження енерговитрат на процес, у яких матеріал проходить обробку послідовно через декілька подрібнювачів і кінцевий ступінь подрібнення досягається поступово [4].

Ефект зменшення енерговитрат на процес подрібнення по багатоступеневій схемі в порівнянні 3 одноступеневою обумовлюється насамперед тим, що в багатоступеневій схемі відбувається процес поступового зменшення розмірів часток i, отже, менша інтенсивність впливу робочих органів на матеріал. У деяких схемах подрібнення при переході від однієї ступені подрібнення до другої, здійснюється видалення подрібнених часток із дробильної камери, що означає, відсутність переподрібнення матеріалу й відбувається зменшення маси циркулюючого навантаження [5].

Недоліками багатоступінчастих способів здрібнювання кормів $€$ те, що матеріал корму проходить обробку через декілька подрібнювачів і кінцевий ступінь подрібнення досягається поступово, при цьому застосовується більш складне, а значить і менш надійне встаткування.

Таким чином, основні недоліки різних типів подрібнювачів: висока енергоємність, можливість додаткового подрібнення часток, інтенсивне спрацювання робочих органів і зв'язку з цим невеликий експлуатаційний період молоткової дробарки, низька якість та рівномірність подрібнення.

Відомо спосіб електроіскрового легування (ЕІЛ), який все ширше застосовується в промисловості для підвищення зносостійкості і твердості поверхонь деталей машин, у тому числі і тих, що працюють в умовах високих температур і агресивних середовищ, для підвищення жаро- і корозійної стійкості, а також для відновлення зношених поверхонь деталей машин при ремонті тощо [6].

ЕІЛ - це процес перенесення матеріалу на поверхню, що обробляється іскровим електричним розрядом. Метод має ряд специфічних особливостей:

- матеріал анода (легуючий матеріал) може утворювати на поверхні катода (легованій поверхні) шар покриття, надзвичайно міцно зчеплений з поверхнею, і в цьому випадку не лише відсутня межа розділу між нанесеним матеріалом і металом основи, але відбувається навіть дифузія елементів анода в катод;

- легування можна здійснювати лише в зазначених місцях (радіусом від часток міліметра і більше), не захищаючи при цьому іншу поверхню деталі;

- технологія ЕІЛ металевих поверхонь дуже проста, а необхідна апаратура малогабаритна і транспортабельна.

Слід відмітити те, що процес ЕІЛ супроводжується збільшенням шорсткості поверхні виробів. При цьому чим більше режим легування, тобто енергія розряду (Wp), тім більша шорсткість поверхневого шару виробу при ЕІЛ.

Відомо, що з метою захисту поверхневих шарів металорізального інструмента й деталей машин від абразивного зношування успішно застосовується метод ЕІЛ [7] и деталей машин [8]. Найбільш значні результати по підвищенню стійкості деталей і металорізальних інструментів від абразивного зношування отримані при використанні електродів сполуки 10 ваг. \% 1M + 90\% ВК6, де $1 \mathrm{M}(70 \% \mathrm{Ni}, 20 \% \mathrm{Cr}, 5 \% \mathrm{~B}, 5 \% \mathrm{Si})$, отриманих способом порошкової металургії. Застосування таких електродів дозволяє формувати методом ЕІЛ на сталевих поверхнях покриття з мікротвердістю 12300...14200МПа [9].

Таким чином, метою роботи $є$ удосконалення способу подрібнення (збільшення експлуатаційного періоду молоткової дробарки, знижування енерговитрат, поліпшування якості та рівномірності подрібнення), шляхом виконання процесу подрібнення матеріалу кормів з використанням одного подрібнювача, тобто одноступінчас- 
тим способом, за рахунок формування методом електроіскрового легування на більш наближених поверхнях молотка та гребінки покрить з зносостійких матеріалів.

Методика досліджень. Заготовки зі сталі 65Г розміром 25×25×50 мм піддавалися загартуванню від $820^{\circ} \mathrm{C}$ в масло і відпустці при $350{ }^{\circ} \mathrm{C}$. Із заготовки вирізали зразки в формі пластинок розміром $15 \times 15 \times 8$ мм.

3 метою визначення впливу енергетичних параметрів ЕІЛ на якісні параметри покриттів, нанесених електродами складу 10\% 1M + 90\% ВК6 на установці моделі «Елітрон 52А» проводили легування зразків сталі 65Г, розміром 15×15x8 мм, 3 використанням різних режимів. Кожному режиму ЕІЛ відповідає своя енергія розряду $\left(W_{p}\right)$ і продуктивність - площа сформованого покриття в одиницю часу (табл.1).

Таблиця 1. Залежність продуктивності ЕІЛ від енергії розряду

\begin{tabular}{|c|c|c|c|c|}
\hline $\begin{array}{c}\text { Енергія розряду } \\
\left(\mathrm{W}_{\mathrm{p}}\right), \text { Дж }\end{array}$ & 0,2 & 0,52 & 2,6 & 4,6 \\
\hline Продуктивність, & $\begin{array}{c}0,5- \\
0,8\end{array}$ & $\begin{array}{c}1,0- \\
1,3\end{array}$ & $\begin{array}{c}1,5- \\
2,0\end{array}$ & $\begin{array}{c}2,0- \\
2,5\end{array}$ \\
\hline
\end{tabular}

Товщину шару покриття вимірювали мікрометром, а шорсткість поверхні - на приладі профрілографі-профілометрі мод. 201 заводу «Калібр» шляхом зняття і обробки профрілограм. Структури поверхневого шару вивчали на оптичному мікроскопі «Неофот-2», де проводилась оцінка якості шару, його суцільності, товщини і будови зон підшарку. Одночасно на мікротвердомірі ПМТ-3 проводили дюрометричний аналіз на розподіл мікротвердості в поверхневому шарі і по глибині шліфу від поверхні при навантаженні на індентор $\mathrm{P}=0.5 \mathrm{H}$.

Результати досліджень. В запропонованому нами новому способі [10] покриття на робочі органи подрібнювача наносять таким чином, що їх товщина та шорсткість, по мірі просування молотка вздовж поверхні гребінки поступово збільшується, а величина зазору між ними, відповідно, зменшується. Матеріал кормів спочатку ударяється об виступи шорсткості покриття, сформованого на торцевій поверхні молотку, потім попадає в найбільший проміжок і руйнується за рахунок одночасного подряпування з обох боків виступами шорсткості покрить, сформованих на поверхнях молотка та гребінки, потім попадає в зону меншого проміжку, де руйнуються, відповідно, його менші частки і нарешті потрапляє в ще менший проміжок, де частки матеріалу кормів досягають потрібного розміру.

Основними перевагами застосування пропонованого способу є:

- підвищення зносостійкості молотків;

- збільшення експлуатаційного періоду молоткової дробарки;
- молоток контактує при ударі не плоскою поверхнею, а окремими виступами, сфрормованої на ній шорсткості, що значно полегшує процес руйнування матеріалу корму;

- зниження енерговитрат;

- поліпшення якості та рівномірності подрібнення.

В табл. 2 зведені якісні параметри поверхневих шарів, сформованих методом ЕІЛ за допомогою електроду-інструменту складу 10\% 1M + 90\% ВК6 на зразках зі сталі 65.

Таблиця 2. Якісні параметри покрить, сформованих на поверхнях зразків зі сталі 65Г

\begin{tabular}{|c|c|c|c|c|c|c|}
\hline 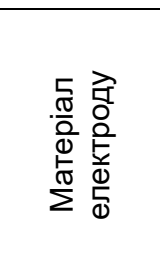 & 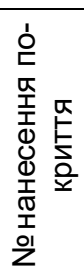 & 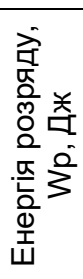 & 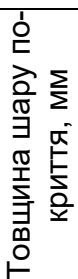 & 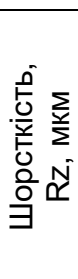 & 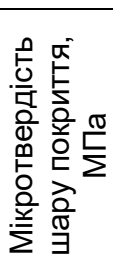 & 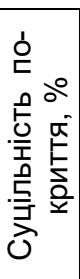 \\
\hline \multirow{4}{*}{$\begin{array}{c}10 \% 1 \mathrm{M}+ \\
90 \% \text { BK6 }\end{array}$} & 1 & 0,2 & 0,02 & 7 & 14000 & 90 \\
\hline & 2 & 0,52 & 0,12 & 21 & 13200 & 85 \\
\hline & 3 & 2,6 & 0,19 & 65 & 12000 & 75 \\
\hline & 4 & 4,6 & 0,23 & 117 & 9000 & 60 \\
\hline
\end{tabular}

Згідно табл. 2, зі збільшенням режиму ЕІЛ збільшується енергія розряду, товщина і шорсткість поверхні нанесеного шару, а мікротвердість і суцільність покриття зменшується. Слід відмітити, що мікротвердість поверхневого шару при нанесенні покриття за допомогою електрода-інструмента складу 10\% 1M + 90\% ВК6, збільшилась в порівнянні з вихідною в 1,8-2,8 разів.

Нижче приводяться приклади використання запропонованого способу.

\section{Приклад 1}

Згідно [11] головним робочим органом молоткової дробарки (подрібнювача) є молотковий ротор. Він складається із валу 1 (Рис. 1) з набором дисків 2, в отворах яких є чотири осі 3 з шарнірно підвішеними молотками 4. Ротор встановлений під днищем бункеру, а знизу закритий змінним решетом 5, що кріпиться болтами до напрямних дуг.

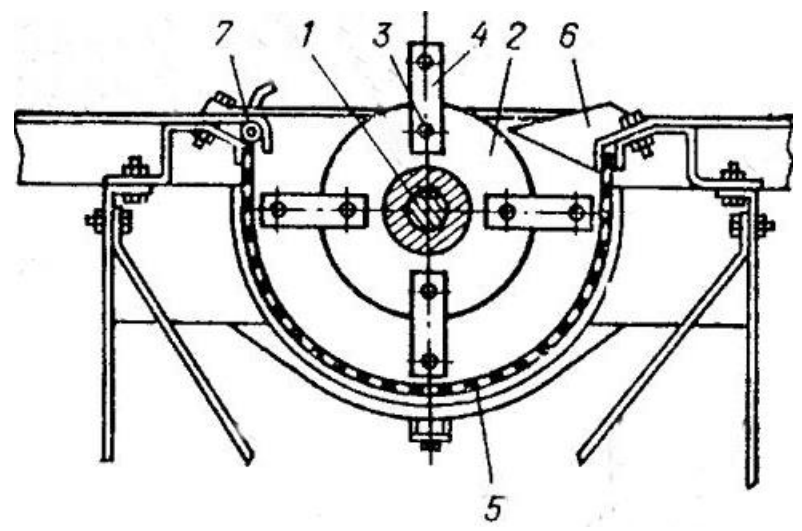

Рис. 1 Подрібнювальний апарат 
Робочий процес подрібнювача проходить так. При обертанні бункера матеріал подається на ротор, затягується молотком між зубцями гребінки 6 в робочу камеру, де в результаті багаторазової взаємодії з молотками, зубцями гребінки та решетом подрібнюється. Продукти подрібнення просіваються крізь решето на горизонтальний транспортер, подаються ним на похилий транспортер і вивантажуються ним в технологічну лінію кормоцеху або в транспортні засоби. Верхнє положення зубців гребінки зменшує навантаження на ротор, а нижче - збільшує. Змінюють положення гребінки 6 за допомогою косих шайб та регулювання труби 7.

Ступінь подрібнення продукту регулюють підбиранням відповідного решета. Подрібнювач комплектується решетами з отворами діаметром 20, 50 та 75 мм.

Запропонований новий спосіб виконують наступним чином.

На установці ЕІЛ, моделі «Елітрон-52А», обладнаній ручним вібратором, окремими ділянками, наносять покриття на поверхні молотка та гребінки, виготовлених зі сталі 65Г, електродом складу 10\% 1M + 90\% ВК6 (відповідно, Рис. 2 і Рис. 3).

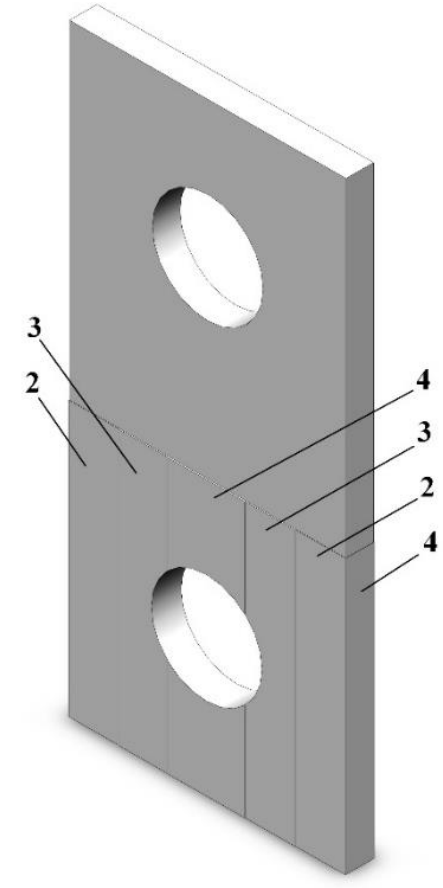

Рис. 2 Молоток зі сталі 65Г з покриттями, сорормованими методом ЕІЛ

При цьому ширина кожної ділянки становить 5-7 мм. Енергія розряду та якісні параметри сформованих покрить, відповідають номеру ділянки, позначеному на Рис. 2 і Рис. 3, який співпадає з номером режиму нанесення покриття, позначеному в табл. 2.

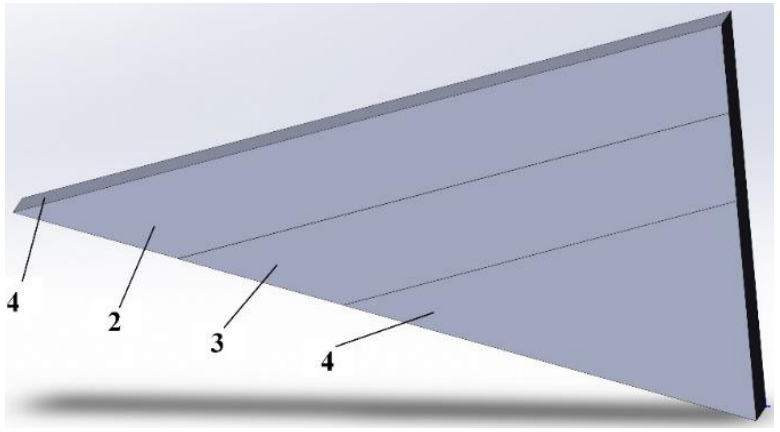

Рис. 3 Гребінка зі сталі 65Г з покриттями, сформованими методом ЕІЛ

Матеріал кормів, просуваючись в проміжку між поверхнями молотка та гребінки, який поступово зменшується поступово руйнується до потрібного розміру.

\section{Приклад 2}

Згідно [12] подрібнювач соковитих кормів ИКС5М (Рис. 4) призначений для миття і подрібнення коренеплодів. Він має приймальний бункер 8, у нижній частині якого $є$ каменеуловлювач 9, гвинтову мийку 10 , зрошувач 11 , барабан подрібнювач 12 , деку 13 , водяний насос 14, ванну для води 15, два електроприводи 16 і 17, фрільтр 18 та люк 19.

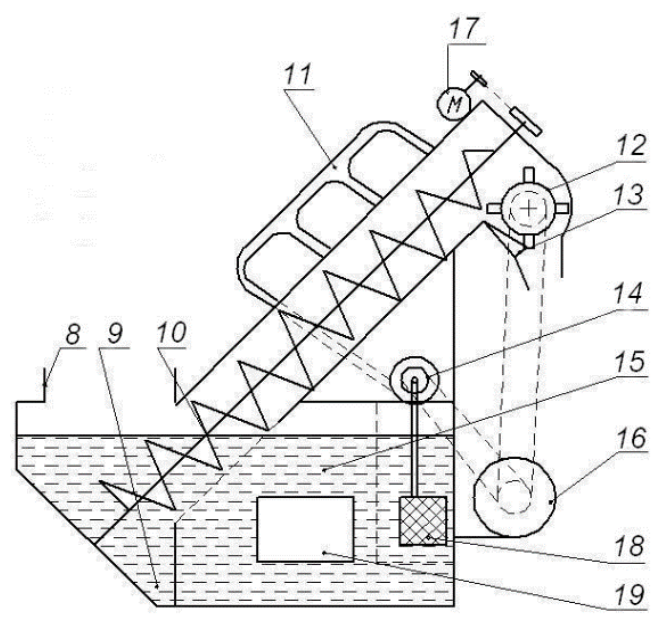

Рис. 4 Конструктивно-фрункціональна схема подрібнювача ИКС-5М

У процесі роботи вимиті коренебульбоплоди потрапляють у подрібнювач під удари шарнірно підвішених молотків, які взаємодіють із зубчастою декою (Рис. 5). Завдяки високій коловій швидкості барабана продукти подрібнення викидаються по напрямному кожуху. Машина налагоджена на одержання пасти з частинками розмірами від 2 до 60 мм і не має пристрою для широкого регулювання ступеня подрібнення коренеплодів. Часткове регулювання ступеня подрібнення продукту можливе шляхом знімання деки (при подрібненні коренебульбоплодів для великої рогатої худоби). 


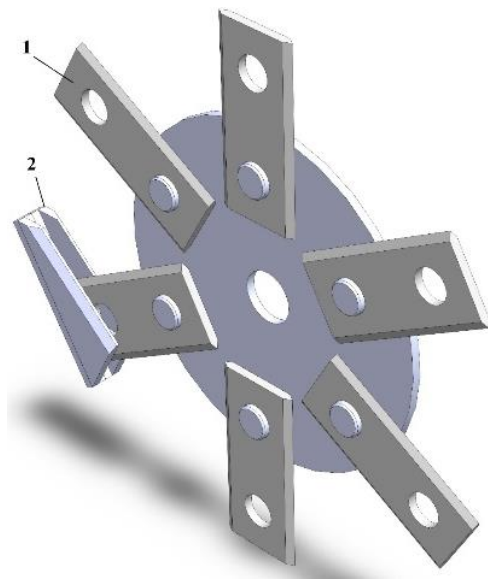

Рис. 5 Взаємодія молотків з декою

На установці ЕІЛ, моделі «Елітрон-52А», обладнаній ручним вібратором, окремими ділянками, наносять покриття на поверхні молотка та деки, виготовлених зі сталі 65Г, електродом складу $10 \%$ 1М + 90\% ВК6 (відповідно, Рис. 6 і Рис. 7).

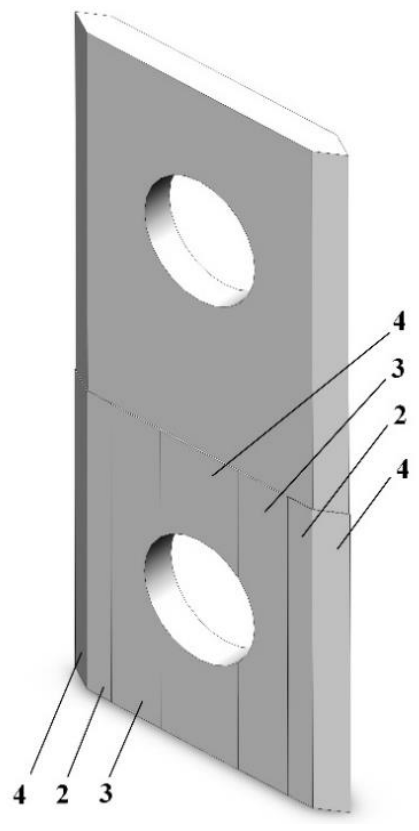

Рис. 6 Молоток зі сталі 65Г з покриттями, сорормованими методом ЕІЛ

При цьому ширина кожної ділянки становить 5-7 мм. Енергія розряду та якісні параметри сформованих покрить, відповідають номеру ділянки, позначеному на Рис. 6 і Рис. 7, який співпадає з номером режиму нанесення покриття, позначеному в табл. 2.

Матеріал кормів, переміщуючись в проміжку між поверхнями молотка та гребінки, який поступово зменшується поступово руйнується до потрібного розміру.

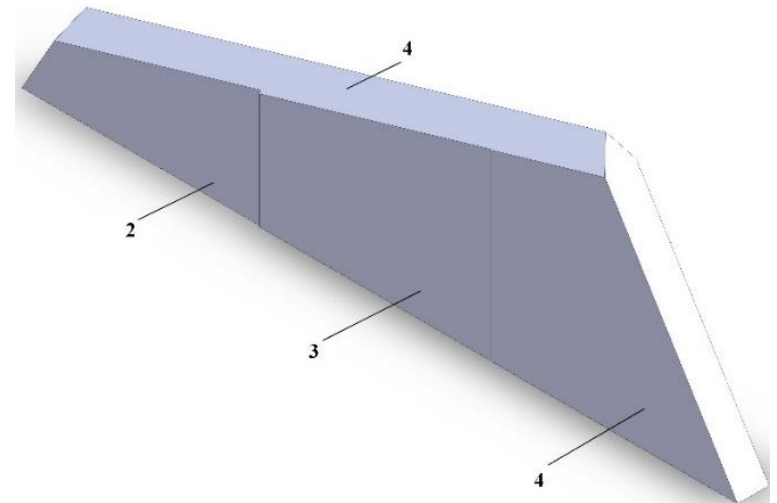

Рис. 7 Дека зі сталі 65Г з покриттями, сформованими методом ЕІЛ

\section{Висновки:}

1. Запропонований новий спосіб подрібнення кормів молотковими дробарками, який відрізняється тим, що на більш наближених поверхнях молотка та гребінки (деки) методом електроіскрового легування наносять покриття з зносостійких матеріалів, причому наносять таким чином, що їх товщина та шорсткість, по мірі просування молотка вздовж поверхонь гребінки (деки) поступово збільшуються, а величина зазору між ними, відповідно, зменшується.

2. Покриття наносять на повітрі окремими ділянками шириною 5-7 мм, при енергіях розряду 0,2; 0,52; 2,6 і 4,6 Дж; продуктивністю - 0,5-0,8; $1,0-1,3 ; 1,5-2,0$ і 2,0-2,5 см2/хв; товщиною - 0,02; 0,12; 0,19 і 0,23 мм і шорсткістю, (Rz) -7; 21; 65 і 117 мкм, відповідно.

3. В якості матеріалу електроду використовують електрод-інструмент складу 10\% 1M + 90\% ВК6. В результаті збільшується експлуатаційний період молоткової дробарки, знижуються енерговитрати, поліпшується якість та рівномірності подрібнення.

\section{Литература:}

1. Ялпачик Ф.Ю., Фучаджи Н.О., Мілаєва В.О. Значення подрібнення у приготуванні корму для тварин//Праці Таврійського державного агротехнологічного університету. 2010. вип.10 Т.3. С. 43-47.

2. Коротов Ю.Ю., Брагінець М. В. Аналіз конструкцій подрібнювачів зернових кормів і напрямки їх вдосконалення// Вісник ХНТУСГ ім. П.Василенка. 2017. вип. 181. С.62-70.

3. Механізація технологічних процесів у тваринництві: Навч. посібник / О.Г. Скляр, Н.І.Болтянська. - Київ: ТОВ «Колор Принт», 2012. - 720 с.

4. Поярков М.С. Совершенствование рабочего процесса молотковых дробилок с жалюзийными сепараторами при одно- и двухступенчатом измельчении зерна. Автореф. дис. канд. техн. наук. Киров - 2001. - 22 с. 
5. Денисов В.А. Повышение эффективности процесса измельчения зерновых компонентов комбикормов: Автореф. дис. д-ра. техн. наук. Москва - 1992. - 32 с.

6. Selected problems of surface engineering and tribology/ edited by B. Antoszewski, V.Tarelnyk Kielce: Wydawnictwo Politechniki Świętokrzyskiej, 2016. - 111p.

7. Підвищення стійкості різального інструменту технологічними методами: навчальний посібник / [Тарельник В.Б., Коноплянченко Є.В., Марцинковський В.С., та ін.]; за ред. профр. В.Б. Тарельника.- Суми: Університетська книга, 2011. - 189 с.

8. Триботехнологія деталей машин: навчальний посібник / Тарельник В.Б., Коноплянченко Є.В., Марцинковський В.С., Антошевський Богдан. - Суми: Видавництво «МакДен», 2010. - 264 с.

9. Спосіб підвищення зносостійкості сталевих виробів: пат. 108866 Україна: МПК В23Н9/00, С23С 4/04, В23Н9/00/ Марцинковський В.С., Тарельник В.Б.; заявл. 05.09.14; опубл. 10.08.16, Бюл. № 15. - 8 c.

10. Спосіб підвищення зносостійкості поверхонь деталей машин способом електроіскрового легування: пат. 141006 Україна: МПК В23Н 5/00 / Тарельник В.Б., Саржанов О.А., Гапон О.О., Саржанов Б.О.; заявл. 19.04.19; опубл. 25.03.20, Бюл. № $6 .-8$ c.

11. Машини та обладнання для тваринництва. Підручник /Науменко О.А., Бойко І.Г., Нанка О.В., Полупанов В.М. та ін.; за ред. І.Г. Бойко. - Том 1. Харків: Видавництво ЧП Червяк, 2006. - 225 с.

12. Ревенко І.І. Машини та обладнання для тваринництва: підручник/ І.І. Ревенко, М.В. Брагінець, В.І. Ребенко. - К.: Кондор, - 2009. - 731 с.

\section{Reference:}

1. Yalpachyk, F.Yu., Fuchadzhy, N.O. and Milaieva, V.O. (2010) The value of grinding in the preparation of animal feed, Proceedings of the Tavriya State Agrotechnological University, 3 (10), pp. 43-47.
2. Korotov, Yu.Yu. and Brahinets, M. V. (2017) Analysis of constructions of grain feed grinders and directions of their improvement, Visnyk of KhNTUSG named after P.Vasilenko, 181, pp.62-70.

3. Skliar, O.H. and Boltianska, N.I. (2012) Mechanization of technological processes in animal husbandry: a textbook. Kyiv: LLC "Color Print", 720 p.

4. Poyarkov, M.S. (2004), Improvement of the working process of hammer crushers with louvered separators in one- and two-stage grain grinding: Author's thesis [Sovershenstvovanie rabochego processa molotkovyh drobilok $s$ zhaljuzijnymi separatorami pri odno- i dvuhstupenchatom izmel'chenii zerna: avtoref. dis. ... kand. tehn. nauk], Kirov, 22 p.

5. Denisov V.A. (1992), Increasing the efficiency of the grinding process of grain components of compound feed: Author's thesis [Povyshenie jeffektivnosti processa izmel'chenija zernovyh komponentov kombikormov: avtoref. dis. ... doct. tehn. nauk ], Moscow, $32 \mathrm{p}$.

6. Electro-spark deposition (2020) Huys Industries Ltd, Available at: http://huysindustries. com/welding-processes/electrospark-deposition/ (Accessed: 20 October 2020].

7. Tarelnyk, V.B. et al. (2011), Increasing the stability of the cutting tool by technological methods: textbook, University Book, Sumy, 189 p.

8. Tarelnyk, V.B. et al. (2010), Tribotechnology of machine parts: textbook, Publishing House McDen, Sumy, $264 \mathrm{p}$.

9. Tarelnyk, V.B. et al. (2016), The method of increasing the wear resistance of steel products, Ukraine Patent 108866.

10. Tarelnyk, V.B. et al. (2020), A method of increasing the wear resistance of the surfaces of machine parts by electrospark alloying, Ukraine Patent 141006.

11. Naumenko, O.A., et al. (2006), Machines and equipment for animal husbandry: textbook, Vol.1, Chervyak Publishing House, Kharkiv, 225p.

12. Revenko, I.I., et al. (2009) Machinery and equipment for animal husbandry: textbook, Condor, Kyiv, $731 \mathrm{p}$.

\section{Аннотация}

\section{Совершенствование способа измельчения кормов молотковыми дробилками}

\section{В.Б. Тарельник, Е.В. Коноплянченко, Е.М. Гецович, М.Я. Довжик}

Приведены преимущества и недостатки способа измельчения зерна молотковыми дробилками. При этом к общим недостаткам различных типов измельчителей отнесены: высокая энергоемкость, необходимость дополнительного измельчения частиц, интенсивное изнашивание рабочих органов и связи с этим небольшой эксплуатационный период молотковой дробилки, низкое качество и равномерность измельчения. В качестве основного недостатка многоступенчатых способов измельчения кормов указано, что материал корма проходит обработку через несколько измельчителей и конечная степень измельчения достигается постепенно, при этом применяется более сложное, а значит и менее надежное оборудование. Обосновано применение одноступенчатого способа измельчения. В работе описана технология увеличения эксплуатационного периода молотковой 
дробилки и улучшения качества и равномерности измельчения кормов путем совершенствования процесса одноступенчатого способа измельчения, за счет формирования методом электроискрового легирования (ЭИЛ) на рабочих поверхностях молотка и гребенки покрытий из износостойких материалов. Приведены результаты легирования образцов стали 65Г, с использованием различных режимов установки модели «Елитрон 52А», с целью определения влияния энергетических параметров ЭИЛ на параметры качества покрытий, нанесенных электродами состава 10\% $1 \mathrm{M}+90 \%$ ВК6. Предложен новый способ измельчения кормов молотковой дробилки. Способ отличается тем, что на более приближенных поверхностях молотка и гребенки (деки) методом ЭИЛ наносят покрытие из износостойких материалов, причем наносят таким образом, что их толщина и шероховатость, по мере продвижения молотка вдоль поверхностей гребенки (деки) постепенно увеличиваются, а величина зазора между ними, соответственно, уменьшается. Покрытие наносят на воздухе отдельными участками шириной 5-7 мм, при энергиях разряда - 0,2; 0,52; 2,6 и 4,6 Дж; производительностью - 0,5 0,8; 1,0 - 1,3; 1,5 - 2,0 и 2,0 - 2,5 см2/мин; толщиной - 0,02; 0,12; 0,19 и 0,23 мм и шероховатостью, (Rz) - 7; 21; 65 и 117 мкм соответственно. В качестве материала электрода используют электрод-инструмент состава 10\% 1M + 90\% ВК6. В результате увеличивается эксплуатационный период молотковой дробилки, снижаются энергозатраты, улучшается качество и равномерности измельчения.

Ключевые слова: молотковая дробилка, молоток, дека, износ, шероховатость, микротвердость, электроискровое легирования.

\section{Abstract}

\section{Improvement of the crushing feed method with hammer crushers}

\section{V.B. Tarelnyk, E.V. Konoplianchenko, E.M. Getsovich, M.Ya. Dovzhyk}

The advantages and disadvantages of the method of grinding grain with hammer crushers are given. At the same time, the general disadvantages of various types of grinders include: high energy consumption, the need for additional grinding of particles, intensive wear of the working bodies and, therefore, a short operating period of the hammer crusher, low quality and uniformity of grinding. As the main disadvantage of multistage methods of grinding feed, it is indicated that the feed material is processed through several grinders and the final degree of grinding is achieved gradually, while more complex, and therefore less reliable equipment is used. The use of a one-stage grinding method is substantiated. The paper describes a technology for increasing the operating period of a hammer crusher and improving the quality and uniformity of feed grinding by improving the process of a one-stage grinding method, due to the formation of coatings made of wear-resistant materials by the method of electrospark alloying (ESA) on the working surfaces of the hammer and the comb. The results of alloying samples of steel $65 \mathrm{G}$, using different modes of the "Elitron 52A" model equipment, in order to determine the influence of the energy parameters of ESA on the quality parameters of coatings deposited with electrodes of composition $10 \% 1 \mathrm{M}+90 \% \mathrm{VK} 6$. A new method of crushing feed of a hammer crusher is proposed. The method differs in that on more approximate surfaces of the hammer and the comb (deck) by the ESA method, a coating of wear-resistant materials is applied, and applied in such a way that their thickness and roughness gradually increase as the hammer moves along the surfaces of the comb (deck), and the gap size between them, respectively, decreases. The coating is applied in air in separate sections 5$7 \mathrm{~mm}$ wide, at a discharge energy of $0.2 ; 0.52 ; 2.6$ and $4.6 \mathrm{~J}$; productivity $-0.5-0.8 ; 1.0-1.3 ; 1.5-2.0$ and $2.0-2.5 \mathrm{~cm} 2 / \mathrm{min}$; thickness - 0.02; 0.12; 0.19 and $0.23 \mathrm{~mm}$ and roughness, (Rz) - 7; $21 ; 65$ and 117 microns, respectively. An electrode-tool of composition $10 \% 1 \mathrm{M}+90 \% \mathrm{BK} 6$ is used as the electrode material. As a result, the operating period of the hammer crusher is extended, energy consumption is reduced, and the quality and uniformity of grinding are improved.

Keywords: hammer crusher, hammer, deck, wear, roughness, microhardness, electrospark alloying.

\section{Бібліографічне посилання/ Bibliography citation: Harvard}

Tarelnyk, V. B. et al. (2020) 'Improvement of the crushing feed method with hammer crushers', Engineering of nature management, (2(16), pp. 38 - 44.

Подано до редакції / Received: 25.08.2020 